\title{
THE EFFECTIVENESS OF CHEMISTRY MEDIA LEARNING BASED ON AUTOPLAY MEDIA STUDIO 8.0 TO IMPROVE STUDENTS' COLLABORATIVE CHARACTER IN ACID-BASE MATERIAL
}

\author{
Irfandi $^{1}$, Maria Erna ${ }^{2}$, Rasmiwetti ${ }^{3}$ \\ 1,2,3 Postgraduate Department of Chemistry Education, FKIP, University Of Riau, \\ Pekanbaru, 28293, Riau, Indonesia
}

Corresponding author: irfandisiuk1@gmail.com

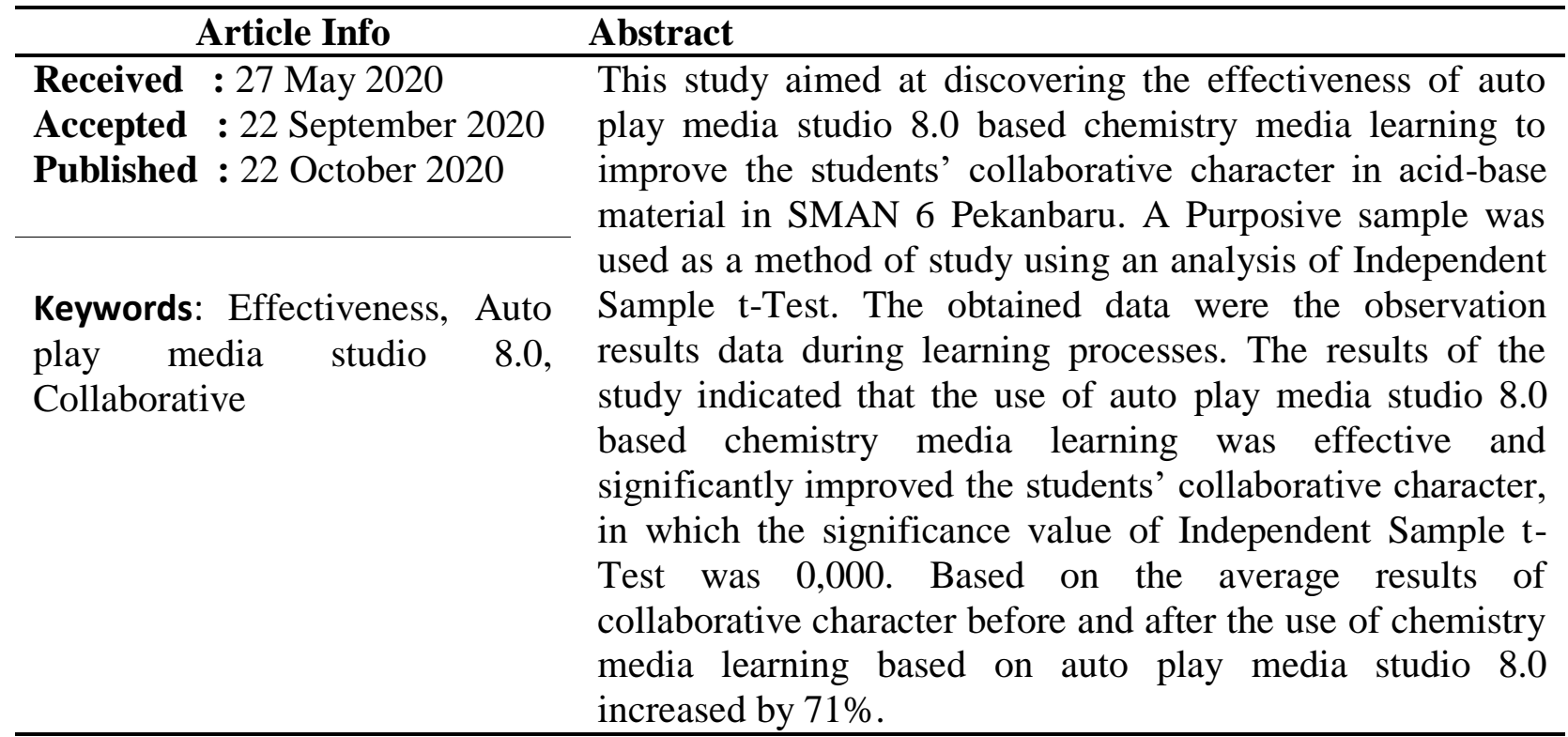

\section{INTRODUCTION}

The $21^{\text {st }}$ century is known as the century of knowledge, the knowledge-based economy century, the information technology century, globalization, and so on. In this $21^{\text {st }}$ century, there are changes that very fast and unpredictable in all aspects of life i.e. economics, transportation, technology, communication, information, education, and others. Very fast changes can give opportunities or chances if it can be utilized well, yet it can be disastrous if not anticipated in a systematic, structured, and measured manner (I Wayan Redhana, 2019). Currently, teachers are urged to develop $21^{\text {st }}$ century skills for the students in school especially in the core skill area (Communication, Collaboration, Critical Thinking, and Problem-Solving and Creativity and innovation) and special skills i.e. the use of Information, Communication, and Technology (ICT) (Ball et al., 2016). 
ICT-based learning is important to be conducted so that the students are accustomed to newer developments of digital technology, of which developments are sophisticated, stable, and unreal; moreover, the students are also accustomed to present new challenges (M. J. Koehler, 2006). The teachers are accused to use more technologies in their teaching. Learning innovation needs to be developed and implemented to prepare the teachers who are ready to act as educators and researchers to encounter the challenges of the $21^{\text {st }}$ century (Hendripides, 2018). The $21^{\text {st }}$ century is the century of knowledge marked by the rapid development of information, communication, and technology (ICT). The development of ICT had a potential in changing the way of a person to learn and obtain information and provide opportunities for teachers to develop instructional techniques for maximum results (Roza et al., 2017). The use of learning media can overcome general obstacles that often occur in the learning processes such as limited hours in class, boredom in the learning process, and the complexity of delivering abstract material (Syaiful Bahri Djamarah, 2008).

ICT has a gap between those who have digital skills and those who do not, between those who have and do not have access to the digital environment. This difference is manifested in access, digital literacy, awareness, and the ability of individuals and organizations to use information technology as a means of production. Developing digital skills is a necessity today, because more and more functions are being carried out in the digital environment in the 21 st century. As a revolutionary and interactive mass Medium, ICT affects society and culture, politics and economics, the public's right to know and the right to privacy, and censorship. It has caused the collapse of hierarchical information, equality of opportunity and social mobility, and for greater interpersonal and mass communication(Castells, 2009; Goyal, 2010; Hsieh et al., 2008; Sascha et al., 2011; Singh, 2008; Smith, 2009; Wang and Chan, 2008; Zilka, 2016). But research (Castells, 2009; Goyal, 2010; Hsieh et al., 2008; Livingstone and Sefton-Green, 2016; Losh, 2004; Sascha et al., 2011; Singh, 2008; Smith, 2009; Wang and Chan, 2008) It has been shown that despite its potential to advance disadvantaged populations, ICT is increasingly expanding their opportunities and limiting the gap between them and the prosperous population. The underprivileged population, disadvantaged in income, housing, and education, often far from the centers of education, business, and commerce, have little or no access to the ICT environment at present.

Behind the various advantages of ICT-based media also has shortcomings, especially if based on the internet. An international study conducted in 25 countries (Livingstone et al., 2012) shows that various risks apply to various age groups: children aged 8-12 face risks related to privacy and exposure to inappropriate content, while adolescents aged 12-17 face the risk of contacting strangers. Both children and adolescents can be confronted with harassment, cyberbullying, identity theft, hate speech, sedition, and racism (Annansingh and Veli, 2016; Gasser et al., 2010; Law et al., 2010; Livingstone et al., 2014 ). The easiest groups are children who are new to the internet, adolescents are actively seeking risks, and children and adolescents are defined as at risk due to reasons such as illness, parental death, behavioral problems, difficulty adapting, financial 
problems, learning disabilities or others, cultural differences, immigration, belonging to a minority, transferring schools, living in problematic, dangerous, or poor neighborhoods, and more (Livingstone et al., 2012; Livingstone and Smith, 2014; Schilder et al., 2016; Zilka, 2016, 2015).

Rotherdam \& Willingham (2009) note that the success of a learner depends on the skills of the $21^{\text {st }}$ century; thus, the students must learn to have the skills. Learning efforts should be more directing the students so that they have a harmonious life such as living together with others, respecting each other's opinions, respecting people speaking, being responsible, willing to sacrifice, accommodating, and having a big spirit. The ways that are considered capable of driving the learning process like this are through collaborative learning. Collaborative character is very important in learning since it involves several students jointly joined in groups that recognize the differences in abilities and contributions of thoughts of each individual. The collaborative character is also reinforced by other characters i.e. communicative, discipline, etc. by using a good communication in learning, there will be a good collaboration since a good collaboration is made of good communication (Vivin Wulandari et al., 2019). Collaborative in learning can motivate the students thru a variety of interactions and knowledge to get a positive result for group and individual (Cheng, 2005; Ebrahim et al., 2009; Thoms, 2011; Xu et al., 2015). The collaborative character utilizes the diversity and group resources and also a difference in individual strength. When a collaborative learning and ICT-based media are combined appropriately, it will provide a positive result in graduate education, particularly in ICTbased learning (Astin, 1997; NSSE, 2003; Hansen, 2006; Antonis et al., 2011; Ku et al., 2013).

Chemistry is a part of natural science that studies the structure of matter and the changes that matter experiences in the scientific process and planned experiments (W. Keenan Charles et.al, 1990). Those material have a high degree of abstractness since it involves the microscopic nature and character of the atom; moreover, this requires the power of imagination to understand it. According to Chang (2005), most of the chemistry is experimental, and most of its knowledge comes from laboratory research. However, nowadays, chemists can use computers to study microscopic structures. Therefore, in order to understand this abstract concept, visualization is needed; thus, it looks as if it is real. Nana Sudjana and Ahmad Rivai (2007) postulate that the students will more easily receive the subject matter if it uses media that can be integrated into teaching and learning activities. The students have difficulty in understanding the invisible material concepts; hence, they need visualization so that the concepts become concrete.

Based on interviews with chemistry teachers at SMAN 2 Pekanbaru and SMAN 6 Pekanbaru, the teachers have a role as the main information provider in the learning process, in which they rarely use ICT-based learning media; therefore, the learning still relies on conventional methods. Additionally, the learning is still dominated by the students who have high abilities, so that the interaction only occurs between the teachers and the smart students. Meanwhile, students with a low level of ability are less involved in learning. This results in a lack of interaction between the students both within the group 
and in the classroom in general. With the teacher as the main information provider, this also makes collaborative students in discussions not run optimally because of the low communication skills between the students. One material that often becomes a problem in learning chemistry is acid-base material. Acid-base materials are generally abstract which require deep understanding and require the students to be more focused on following the learning process so that the concepts described can be understood by the students.

One of the efforts that can be carried out to overcome the above problems is by developing a learning media that can attract the students' attention so as to facilitate the thinking process of students to understand the intent of the material presented and it can create independence on the students. The position of teachers in the era of industrial revolution 4.0 tends to be facilitators who provide the latest information related to scientific developments to the students from various sources; hence, the teachers must have competence in the technology and digital fields (Risky Setiawan et al., 2019). Azhar Arsyad (2011) asserts that the complexity of the material presented to the students can be simplified with the assistance of the media. One of programs that can be developed to be an interested learning media is Autoplay Media Studio 8.0 program.

The Autoplay Media Studio 8.0 is used since this application is in the form of a multimedia software by integrating various types of media i.e. text, images, voices, videos, texts, and flash into the presentation made (Kuswari Hernawati, 2010). Using integrated media skills like this will assist the process of knowledge construction in a game-friendly and game-oriented manner, and multiple sources of information, data processing programs, and many more (Ching et al., 2005; Hatlevik et al., 2015; Zilka, 2011, 2012, 2014, 2017).

Besides being sophisticated, Autoplay Media Studio 8.0 is also widely used since it is easier and it has very good quality learning media. The software of Autoplay Media Studio 8.0 can be used to develop multimedia application, Computer Based Training (CBT) application, system of AutoPlay/AutoRun menu CD-ROOM, presentation of marketing interactive, CD Business Cards, and so on (Hernawati, 2014). ). Further research conducted at Wilfrid Laurier University (1998) Canada (Surjono, 1999) found that students who use ICT-based media in their learning proved to be twice as fast learning time as classical students, $80 \%$ of these students perform well and very well, and $66 \%$ of them do not need printed material (hard copy). Other than that, research by Supriyono (2014) shows that the development of ICT-based learning media that is effective web is used in the learning process because it is able to increase the average student learning outcomes from $43 \%$ to $86 \%$ with a classical mastery level of $4 \%$ to $90 \%$.

\section{METHODOLOGY}

This study used experimental method with a purposive sampling design involving two groups, namely experimental and control groups. Both groups were assumed to be the 
same in all relevant aspects and only differed in the treatment of learning media. The experimental group was given a treatment in the form of learning that chemistry media learning based on autoplay media studio 8.0, while the control class used PowerPoint media in acid base material.

Population of this study was the students of $11^{\text {th }}$ grade in SMAN 6 Pekanbaru. From the population, 2 classes were taken as samples. Moreover, the two classes had an initial ability that was homogenous and normally distributed, namely $11^{\text {th }}$ classes of Mathematics and Natural Science (MIPA) 3 and 5.

There were two data of this study that would be used for research purposes. Those data covered up the enhancement of students' collaborative character, of which data were gained by means of an observation. Prerequisite tests used in variance analysis ware normality and homogeneity tests. Hypothesis of this study was that there is an increase of the use chemistry media learning based on autoplay media studio 8.0 to the students' collaborative character in acid base material. Hypothesis testing of this study used SPSS V 23 along with the independent sample t test which had stipulation that the Ho was received when the sign $>0,005$.

\section{FINDINGS AND DISCUSSIONS}

The results showed the collaborative character of students increased by using chemistry media learning based on autoplay media studio 8.0 compared to conventional media. The collaborative aspects of students in the experimental class were also higher than the control class at $71 \%$ while the control class was only $47.50 \%$. Comparison of improvement between the experimental and control classes can be seen in Figure 1.

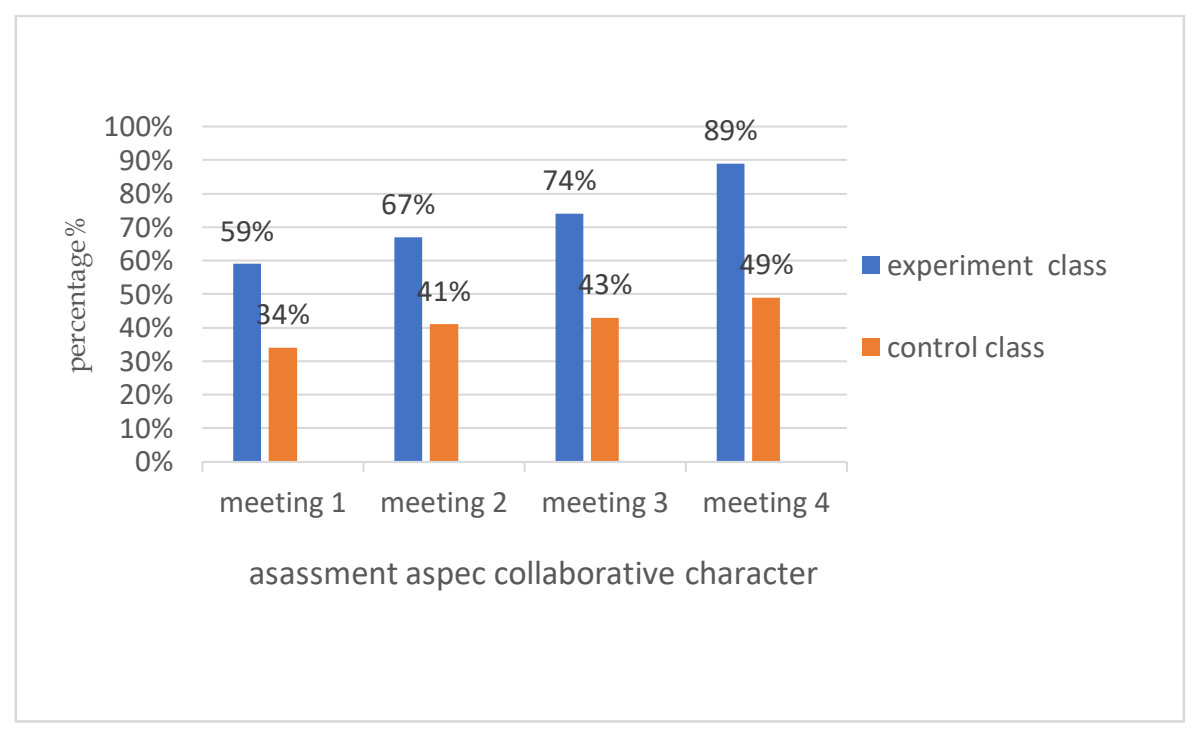

Figure 1. Graphic enhancement of students' collaborative character 
The next step is to do a T Test on the data obtained. This test is carried out to see the significance of the character differences before and after the use of the product being developed. $T$ test used was independent sample $t$ test. $T$ test results can be seen in table 1 .

Table 1. Results of the independent sample t-test collaborative character

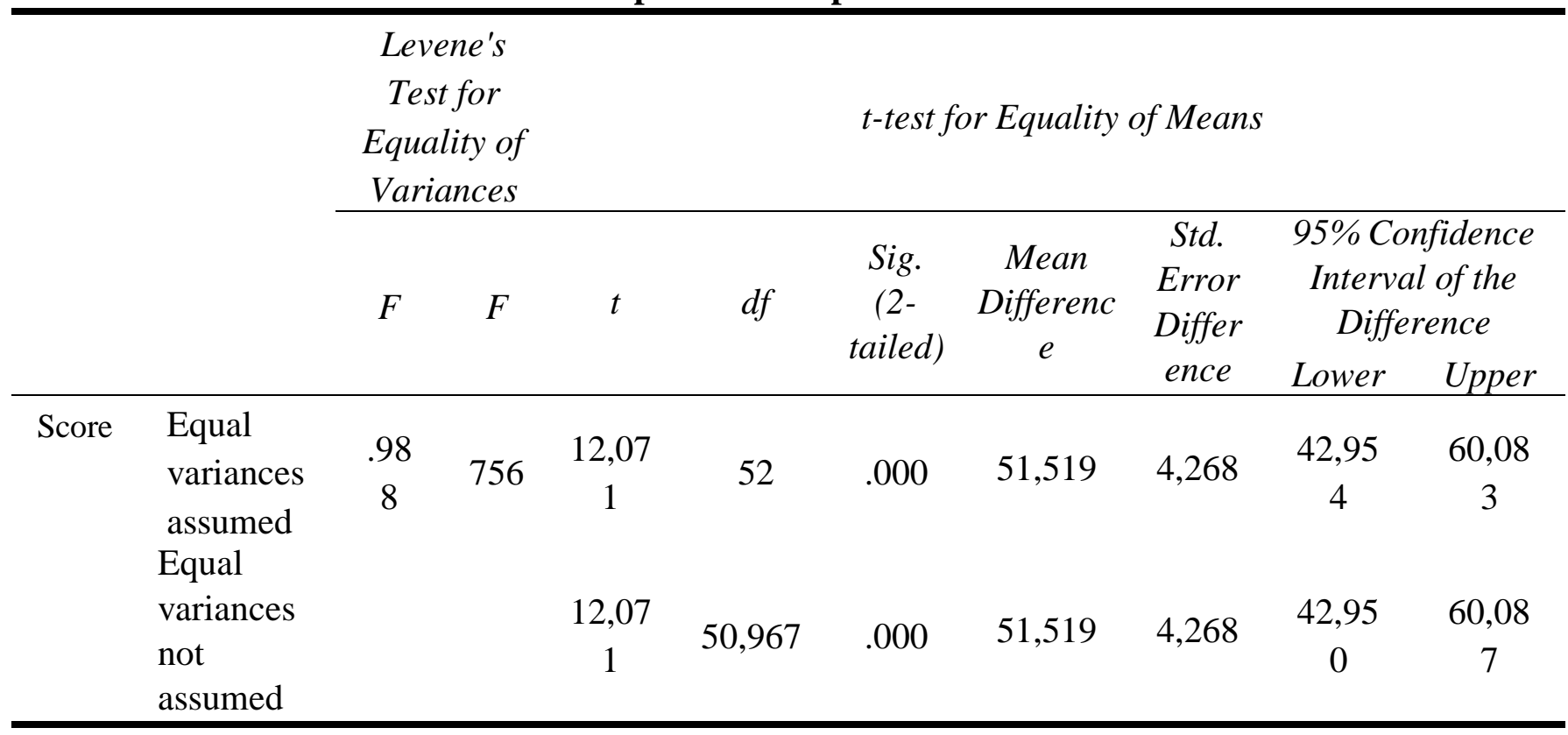

T-test results using independent sample t-test showed that the significance was 0,000 $<0.005$ which showed that there were significant differences in the students' collaborative characters before and after the use of learning media based on autoplay media studio 8.0. meaning that Ha was accepted and Ho was rejected, namely a significant difference from the use of media learning media based on Autoplay studio media 8.0 compared to conventional media on the material. acid base. Chemistry media learning based on autoplay media studio 8.0 that was developed contains some activity instructions that lead students to carry out a series of communication activities. With this guidance the students will be motivated and encouraged to interact and communicate with both the teacher and fellow students. This is in line with the position of the learning media is as a learning component that can improve the interaction of teachers, students and the learning environment. Whereas in other learning media not given these instructions so that the interaction that occurs is only one-way interaction between teacher and student. These results are in line with Arsad Bahri (2018) that an increase in student learning outcomes from cycle 1 to cycle 2 . In cycle 1 , there were no students in the excellent category, $61.9 \%$ of students were in the good category and $38.1 \%$ were in the moderate category. While in cycle 2 , there were $42.8 \%$ of students in the excellent category, $42.8 \%$ in the good category, 4.76 in the moderate category and $9.52 \%$ in the poor category. An increase in average student learning outcomes as a result of the use of learning media based on Autoplay Media Studio 8. 
ICT-based interactive learning media design aims to clarify the presentation of messages and information and can overcome the limitations of the senses, space, time, and objects and objects that are too big or too small that are not visible to the senses that can be presented with the help of films, slides, videos, animations or pictures (Trianto, 2010). The use of elements in the form of text, graphics, images, photos, audio, video and animation in ICT-based learning media can illustrate the chemical concept that includes both macroscopic and microscopic aspects of study so that students can have complete mastery of concepts (Sadiman et al., 2011 ). Basically the design of ICT learning media refers to the use of technology in learning activities (Naidu, 2006). ICT-based learning media suitable for use as a learning tool that can access information on learning content, communication and interaction between teachers and students (Burgess and Ice 2011); (Sharma., et al, 2014). According to Davidson and Rasmussen (2006) there are several important aspects in the development of ICT-based learning media including the delivery of content and communication.

ICT-based learning is important so that students are accustomed to the development of newer digital technologies, which are sophisticated, stable, and unreal and are accustomed to presenting new challenges (M.J Koehler, 2006). Educators are required to use more technology in their teaching.Learning innovations need to be developed and implemented in order to prepare teachers who are ready to act as educators and researchers to face the challenges of the 21 st century (Hendripides, 2018). The position of the learning media is as a learning component that can improve the interaction of teachers, students and the learning environment (K.A Peppler and YB Kafai, 2007). Learning media can accelerate the learning curve and can attract students' interest rather than just listening to the teacher's explanation (N. Kittidachanupap, et al. 2012). Another advantage of developing ICT-based media by Nguyen (2015) is that it can effectively teach students material, cost efficiency and provide a modern education. One of the determinants of student learning success is the learning media used by a teacher. the use of instructional media in the learning process can generate new enthusiasm, generate motivation and stimulation of learning activities, and even bring psychological effects on students so that the collaborative character can be well explored (J. Handhika, 2012). The 21st century is a century of knowledge marked by the rapid development of technology, information, and communication. The development of ICT has the potential to change the way a person learns and obtains information and provides opportunities for teachers to develop instructional techniques to get maximum results (Roza et al., 2017).

ICT learning media has become a necessity in the learning process. Media is everything that can be used to channel messages, stimulate thoughts, feelings, attention and willingness of students so that students can be encouraged and involved in the learning process (Angkowo and Kosasih, 2007). The use of instructional media can overcome common obstacles that often occur in the learning process, such as limited hours in class, boredom in the learning process, and the complexity of delivering abstract material (Syaiful Bahri Djamarah, 2008). Mills (2006) further states that integrating ICT into the classroom curriculum becomes an inseparable part of good teaching.

International Journal of Educational Best Practices (IJEBP)

Vol. 4 No. 2 October 2020

ISSN: 2581-0847

DOI: 10.32581/ijebp.v4n2.p33-47 
Chemistry media learning based on Autoplay media studio 8.0, has an advantage compared to conventional media such as power point. By using the media of learning chemistry based on Autoplay media studio 8.0, the teacher can develop media that is in accordance with the character of students by providing instructional texts that can encourage students to carry out collaborative activities. Besides animation, simulations can also be made through programs. Power points can also display animations and simulations, but can only be displayed using hyperlinks. Navigation buttons made through the Autoplay media studio 8.0 program are also more interesting. Autoplay media studio 8.0 can integrate all types of learning media in it, so students who use Autoplay media studio 8.0 have better learning achievements compared to conventional media such as power points.

The increase in student character that occurred in the learning process was due to the presence of visual media in the form of Autoplay Media Studio 8.0 which attracted the students' attention so that it stimulated the students to discover more information about the teaching materials. This could make the students to be active in the learning process. As stated by Bakrowi's (2007), one of the advantages of utilizing the ICT-based learning media is as a learning medium, one of which is the class presentation stage that usually makes the students who are passive to become active. Learning is interesting for students because the material explanation from the teacher is presented in the form of impressive pictures and animations. This is also emphasized by Harun and Zaidatun (2010) who state that one of the advantages of ICT media is that animation when used in education can offer a more enjoyable learning. Animations are able to attract the attention, increase motivation and activity, and stimulate more memorable student thinking.

The autoplay media was also effective since the Autoplay media studio 8.0 based chemistry media learning in acid-base material loaded several instructions that directed the students to carry out collaborative activities as shown in the figure 2.

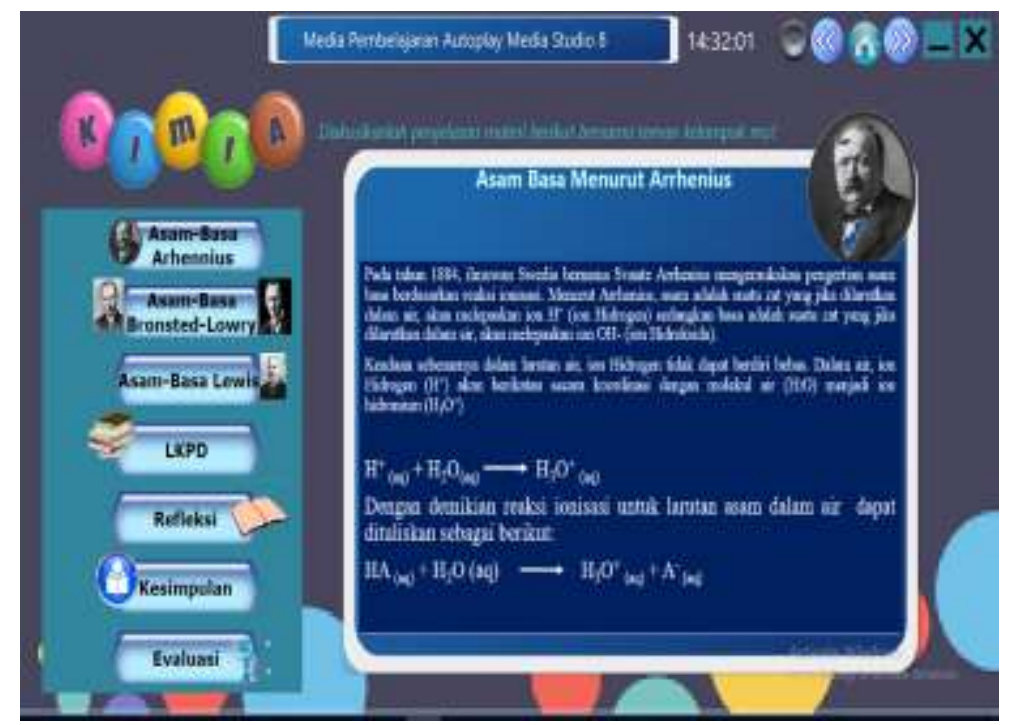

Figure 2. Example of media display

International Journal of Educational Best Practices (IJEBP)

Vol. 4 No. 2 October 2020

ISSN: 2581-0847

DOI: 10.32581/ijebp.v4n2.p33-47 
The students who usually only wait the teacher's direction, now guided through the instructions in the media. This was in line to the statement of Bakrowi (2007) that one of the excellences of Autoplay Media Studio based learning media is that it can make the students' concentration can be fully focused on the learning presented. This was an important result, because by concentrating the students on interesting learning materials would create quality student learning outcomes will be create quality students' learning outcomes.

The use of Autoplay Media Studio 8.0 software-based learning media could generate the learning motivation which further improved the student character and eased the students to understand the material as shown in Figure 3.

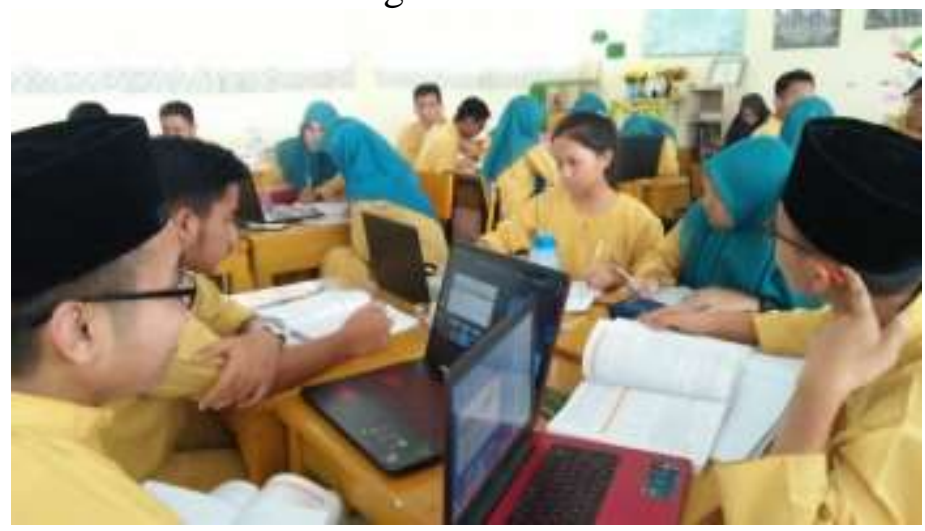

Figure 3. Student discussion activities

This would have an impact on improving the students' cognitive learning outcomes. This showed that the character possessed by the students had an important role in improving the students' learning outcomes. This was supported by various studies that showed a relationship between motivation, learning activities, and increased student cognitive learning outcomes. There is a relationship between activity, learning motivation, and learning outcomes (Nugraheni, 2009). There is a positive and significant influence between activities, learning motivation on student learning activities, learning motivation on student life characters, and the students' learning activities on the student life characters. The implication is that as an effort to improve the character of student life, it is necessary to increase the students' learning motivation and the students' learning outcomes (Kiswoyowati, 2011).

Team and individual learning outcomes largely depended on how the team members performed collectively, how they collaborated with one another, and how the team as a whole acted when given problems. Generally, the performance of collaborative teams depended on respect, preferred learning styles, personality, trust, communication, and togetherness, in which it was demonstrated by organizational learning, communication tools, information sharing methods and tools, etc.), team abilities (demonstrated by selfstudy ability, subject skills/knowledge, team ability, etc.), teaching/learning methods, and others (Astin, 1997; Thompson et al., 2009; Qiu, 2010). 
Various collaborative behaviors, such as time to communicate, frequency of interaction in teams, and how team members communicate, the frequency of individual class discussion participation, etc., greatly influence student collaborative (Selim, 2007). Although it has been well proven in empirical studies that group structure or components and characteristics of information flow have a major impact on the effectiveness of team interaction and collaboration(Imel, 1991; Smith and Smarkusky, 2005; Marks et al., 2005; Thompson et al., 2009; Qiu, 2010, Ku et al., 2013),, a relatively quantitative understanding of the dynamics of the learning service system is of great potential.

\section{CONCLUSION}

Autoplay media studio 8.0 based chemistry media learning in acid-base material is effective to improve the students' collaborative character at SMAN 6 Pekanbaru with a significant enhancement, in which the averages are $71 \%$ of collaborative character. Moreover, the result of independent sample $t$ test is $0,00<0,005$.

\section{REFERENCES}

Angkowo., Kosasih. (2007). Optimalisasi Media Pembelajaran. PT. Grasindo, Jakarta.

Annansingh, F. and Veli, T. (2016). An investigation into risks awareness and eSafety needs of children on the internet: a study of Devon, UK. Interactive Technology and Smart Education, Vol. 13, No. 2.

Antonis, K., Daradoumis, T., Papadakis, S. and Simos, C. (2011). Evaluation of the effectiveness of a web-based learning design for adult computer science courses. IEEE Transaction on Education, Vol. 54, No. 3, pp.374-380.

Arsad Bahri., Wahyu Hidayat., and Abdul Qalam Muntaha. (2018). Penggunaan Media Berbasis AutoPlay Media Studio 8 untuk Meningkatkan Aktivitas dan Hasil Belajar Siswa: Sebuah Inovasi Media Pembelajaran. Proceeding Biology Education Conference, Vol. 15, No.1, pp.394-402.

Astin, A. (1997). What Matters in College? Four Critical Years Revisited. Jossey-Bass, San Francisco, CA.

Azhar Arsyad. (2011). Media Pembelajaran’, PT Raja Grafindo Persada. Jakarta.

Bakrowi. (2007). Microsoft Power Point sebagai Media Pembelajaran Materi Unsur, Senyawa, dan Campuran Berbasis STAD. Retrieved from: (http://jurnalpi. files.wordpress.com) 28 April 2020. 
Ball, Annahita; Joyce, Hillary D.; and Anderson-Butcher, Dawn .(2016). Exploring 21st Century Skills and Learning Environments for Middle School Youth. International Journal of School Social Work. Vol. 1: Iss. 1.

Burgess, M. L. \& Ice, P. (2011). Using the Community of Inquiry (CoI) Model and Bloom's Revised Taxonomy to Support 21st Century Teaching and Learning in Multi-User Virtual Environments. Cutting-edge Technologies in Higher Education. Vol 4. pp.163-186.

Castells, M. (2009). Communication Power. Oxford University Press, New York.

Cheng, Y. (2005). New Paradigm for Re-engineering Education, Globalization, Localization and Individualization. Springer, Netherlands.

Ching, C.C., Basham, J.D. and Jang, E. (2005). The legacy of the digital divide, gender, socioeconomic status, and early exposure as predictors of full spectrum technology use among young adults. Urban Education, Vol. 40, pp.394-411.

Clark, R., Nguyen, F., and Sweller, J. (2006). Efficiency in Learning'. Evidence-based Guidelines to Manage. Cognitive Load. Pfeiffer.

Davidson, G.V. \& Rasmussen, K.L. (2006). Web based learning: designing, implementation, and evaluation. Upper Saddle River, NJ: Pearson Education, Inc.

Goyal, A. (2010). Information, direct access to farmers, and rural market performance in centralIndia. American Economic Journal: Applied Economics, Vol. 2, No. 3, pp.22-45.

Hansen, R. (2006). Benefits and problems with student teams: suggestions for improving team projects. Journal of Education of Business, Vol. 82, No. 1, pp.11-19.

Harun and Zaidatun. (2004). Teknologi Multimedia dalam Pendidikan. Retrieved from: (http://www.ctl.utm.my/publications/manuals/m m/elemenMM.pdf) 28 April 2020

Hatlevik, O.E., Guðmundsdóttir, G.B. and Loi, M. (2015). Examining factors predicting students' digital competence. Journal of Information Technology Education Research, Vol. 14, pp.123-137.

Hendripides, S., Hikmah, N. (2018). Development of Innovative Teaching Materials through Scientific Approach. Journal of Educational Sciences, 2(2), 14-22.

Hsieh, J.J., Rai, A. and Keil, M. (2008). Understanding digital inequality: comparing continued use behavioral models of the social-economically advantaged and disadvantaged. MIS Quarterly,Vol. 32, pp.97-126. 
I Wayan Redhana. (2012). Model Pembelajaran Berbasis Masalah dan Pertanyaan Socratik Untuk Meningkatkan Keterampilan Berpikir Kritis Siswa. Jurnal UNY, No 3 tahun 31, Yogyakarta.

Imel, S. (1991). Collaborative learning in adult education. ERIC Clearing on Adult Career and Vocation Education, Columbus, OH, ERIC Digest No. 113.

J. Handhika. (2012). Efektivitas media pembelajaran im3 ditinjau dari motivasi belajar. Jurnal Pendidikan IPA Indonesia. Vol. 1 (2), 109-114

K. A. Peppler and Y. B. Kafai, (2007). From SuperGoo to Scratch : Exploring Creative Digital Media Production in Informal Learning, Learning, Media an Technology.

Keenan, W. Charles. (1990). Kimia untuk Universitas. Erlangga. Jakarta.

Kiswoyowati, A. (2011). Pengaruh Motivasi Belajar dan Kegiatan Belajar Siswa terhadap Kecakapan Hidup Siswa. Jurnal Kajian Filosofi, Teori, Kualitas, Dan Manajemen Pendidikan Educationist, Edisi Khusus No. 1, pp.120-126.

Ku, H.Y., Tseng, H.W. and Akarasriworn, C. (2013). Collaboration factors, teamwork satisfaction, and student attitudes toward online collaborative learning. Computers in Human Behavior, Vol. 29, No. 3, pp.922-929.

Kuswari Hernawati. (2009). Modul Pelatihan Autoplay Media Studio. FMIPA Universitas Negeri Yogyakarta. Yogyakarta.

Law, D.M., Shapka, J.D. and Olson, B.F. (2010). To control or not to control? Parenting behaviours and adolescent online aggression. Computers in Human Behavior, Vol. 26, No. 6, pp.1651-1656.

Livingstone, S. and Sefton-Green, J. (2016). The Class: Living and Learning in the Digital Age, NYU Press, New York.

Livingstone, S. and Smith, P. (2014). Annual research review: children and young people in the digital age: the nature and prevalence of risks, harmful effects, and risk and protective factors, for mobile and Internet usage. Journal of Child Psychology and Psychiatry: Annual Research Review, doi: 10.1111/jcpp.12197.

Livingstone, S., Haddon, L. and Görzig, A. (Eds) (2012). Children, Risk and Safety on the Internet: Research and Policy Challenges in Comparative Perspective. Marston Books, Policy Press, Briston, UK.

Livingstone, S., Kirwil, L., Ponte, C. and Staksrud, E. (2014). In their own words: What bothers children online?. European Journal of Communication, Vol. 29, No. 3, pp.271-288. 
Losh, S.C. (2004). Gender, educational, and occupational digital gaps. Social Science Computer Review, Vol. 22, No. 2, p.152.

M. J. Koehler, and P. Mishra. (2006). What is technological pedagogical content knowledge?', Contemporary Issues in Technology and Teacher Education,

N. Kittidachanupap, J. Singthongchai, E. Naenudorn, N. Khopolklang, and S. Niwattanakul,॥ , (2012). Development of Animation Media for Learning English Vocabulary for Children' Conference Paper.

Naidu, S. (2006). E-Learning A Guidebook of Principles, Procedures and Practices', Commonwealth of Learning Media Centre for Asia, Australia.

Nana Sudjana and Ahmad Rivai. (2007). Media Pengajaran. Sinar Baru Algesindo. Bandung.

NSSE (2003). National Survey of Student Engagement: The College Student Report. Annual Report, Center for Postsecondary Research, Indiana University, Bloomington, IN.

Nugraheni, F. (2009). Hubungan Motivasi Belajar terhadap Hasil Belajar', Mahasiswa (Studi Kasus pada Mahasiswa Fakultas Ekonomi UMK). Retrieved from: (http://eprints.umk.ac.id/144/1/HUBUNGAN_MOTIVASI_BELAJAR.pdf) 28 April 2020.

Qiu, R.G. (2010). A collaborative model of engineering education for complex global environments. The 40th ASEE/IEEE Frontiers in Education Conference, Washington, DC, pp.S3J1-S3J5

Risky Setiawan, Djemari Mardapi, Afis Pratama, and Syahri Ramadan. (2019). Efektivitas blended learning dalam inovasi pendidikan era industri 4.0 pada mata kuliah teori tes klasik. Jurnal Inovasi Teknologi Pendidikan. Volume 6, No. 2, $148-157$

Rotherdam, A. \& Willingham (2009). To work, the 21st century skills movement will require Keen Attention To Curriculum, Teacher Quality, and Assessment. Educational Leadership, Vol 67 (1), Alexandria.

Roza, Y., Yuanita, P., Saragih, S., Alfajri, H., and Saputra, A. (2017). Computer-Based Media for Learning Geometry at Mathematics Class of Secondary Schools. Journal of Educational Science, Vol. 1, No. 1, pp.79-91.

Sascha, M.S., James, L. and James, L. (2011). A growing digital divide: internet freedom and the negative impact of command-and-control networking. New America Foundation, Internet Computing, IEEE, Vol. 15, No. 4, pp.75-79. 
Schilder, J.D., Brusselaers, M.B. and Bogaerts, S. (2016). The effectiveness of an intervention to promote awareness and reduce online risk behavior in early adolescence. Journal of Youth and Adolescence, Vol. 45, No. 2, pp.286-300.

Selim, H. (2007). Critical success factors for e-learning acceptance: confirmatory factor models. Computers and Education, Vol. 49, pp.396-413.

Sharma, S. K., Chen, R.,\& Zhang, J. (2014). Examining Usability of E-learning SystemsAn Exploratory Study (Research-in-Progress). International Conference on Education, Research and Innovation. IPEDR Vol. 81, pp 120-123.

Singh, N. (2008). Crossing a chasm: technologies, institutions and policies for developing aregional IT industry', Saith, A., Vijayabaskar, M. and Gayathri, V. (Eds): ICTs and Indian Social Change: Diffusion, Poverty and Governance, Sage, New Delhi, pp.192-218.

Smith, H. and Smarkusky, D. (2005). Competency matrices for peer assessment of individuals in team projects. Proceedings of the 6th Conference on Information Technology Education, pp.115-162.

Smith, R.H. (2009). Social interactions and the "Digital Divide": explaining variations in internet use. Information Systems Research, Vol. 20, No. 2.

Supriyono, K., \& Sugirin, S. (2014). Pe-ngembangan media pembelajaran membaca bahasa inggris smp ber-basis web. Jurnal Inovasi Teknologi Pendidikan, 1(1), 4964.

Surjono, H. D. (1999). Pemanfaatan internet untuk memperbaharui model peng-ajaran di perguruan tinggi. Cakrawala Pendidikan. No.4 (XVII): 162-166.

Syaiful Bahri Djamarah. (2008). Guru dan Anak Didik dalam Interaksi Edukatif:Suatu Pendekatan Teoritis dan Psikologis. Edisi Revisi, Rineka Cipta, Jakarta. vol. 9, pp. $60-70$

Thompson, A., Perry, J. and Miller, T. (2009). Conceptualizing and measuring collaboration. Journal of Public Administration Research and Theory, Vol. 19, No. 1, pp.23-56.

Thoms, B. (2011). A dynamic social feedback system to support learning and social interaction in higher education. IEEE Transactions on Learning Technologies, Vol. 4, No. 4, pp.340-352.

Vivin Wulandari, Maria Erna, and Rasmiwetti. (2019). Efektivitas Model Pembelajaran Berbasis Masalah Dan Inkuiri Terhadap Karakter Komunikatif Pada Materi Termokimia. Jurnal Tadris Kimiya, Vol 4, No. 1, pp. 57-68. 
Wang, D., Xu, L. and Chan, H.C. (2008). Understanding users' continuance of Facebook: the role of general and specific computer self-efficacy. Proceedings of the International Conferenceon Information Systems (ICIS 2008).

Xu, J., Du, J. and Fan, X. (2015). Students' groupwork management in online collaborative learning environments. Educational Technology \& Society, Vol. 18, No. 2, pp.195-205.

Zilka, C.G. (2011). Digital environment in the kindergartens, in Chen, D. and Kurtz, G. (Eds): ICT Learning and Teaching, The Center for Academic Studies, pp.207230 .

Zilka, C.G. (2012). Reducing the digital gap among underserved populations in Israel. Ma'of uMa'aseh (Vision and Action) - Teaching and Learning in the Internet Era 14, Achva Academic College, pp.101-138.

Zilka, C.G. (2014). Empowering parents in the social media age - The Three Element Way. Bitan Galim, Tel Aviv.

Zilka, C.G. (2016). Reducing the digital divide among children who received desktop or hybrid computers for the home. Journal of Information Technology Education Research, Vol. 15, pp.233-251.

Zilka, C.G. (2017). Awareness of ICT capabilities, digital literacy, and use of reflective processes in children who received their first home computer. Journal of Technology Enhanced Learning, Vol. 15, pp.233-251. 